\title{
KELUARGA TRADISIONAL DAN MODERN (DUAL CAREER), TIPOLOGI DAN PERMASALAHANNYA
}

\author{
David Ilham Yusuf, dkk \\ Fakultas Dakwah IAIN Jember
}

\begin{abstract}
This study aimed at understanding the kinds of issues occur in families which apply traditional pattern and modern pattern or known as dual-career family (both husband and wife are employed). This descriptive qualitative study had eight (8) families as the respondents. Four families were considered as traditional families, while the other four applied modern pattern or known as dual-career families. The data were obtained from interviews and observations which were then triangulated to validate the data. The current study revealed the following issues as the results found in traditional family: First, husbands expected wives to have a job which were followed with the use of harsh words towards their wives. The second issue, husbands were negligent towards child care and education as they considered children as wives' responsibility. Third, extramarital affair caused by unsatisfied spouses and lack of affection from their respective partners. As for the issues emerged in a modern or dual-career family are stated as follows: First, the dual-role of a wife which later sparked family conflicts. Second, a very limited family time, and the third was the lack of affection from their respective spouses.
\end{abstract}

Keywords: Traditional marriage, Modern Family Marriage, Family Issues.

\section{Pendahuluan}

Secara umum suami adalah orang yang bertugas mencari nafkah untuk kebutuhan sandang, pangan, papan istri dan anak- anaknya. Suami berperan sebagai mitra istri, sedangkan istri berperan sebagai ibu dan wanita yang mendampingi suami dalam suka dan duka. Tidak hanya itu, Istri juga berperan sebagai pemelihara rumah tangga dan memberikan kontribusi yang sangat luar biasa dalam keutuhan rumah tangga dan di masyarakat. Dengan kata lain antara suami dan istri terpatri secara budaya mempunyai tugas dan kewajiban masing-masing.

Pembagian tugas dan peran dalam rumah tangga yang adil antara suami dan istri terkadang dipengaruhi oleh gender yang cenderung memposisikan wanita hanya berperan pada wilayah domestik semata. Rahayu menyebut po- 
la pembagian peran dalam keluarga dipengaruhi oleh beberapa hal seperti, Pertama, kebijakan pemerintah yang tertuang dalam berbagai peraturan, salah satunya kebijakan yang tidak adil menurut gender, karena menganut sistem patriarki. Kedua, faktor pendidikan. Masih banyak individu yang memiliki pola pikir bahwa laki-laki menjadi pemimpin, sedangkan anak perempuan hanya menjadi ibu rumah tangga sekalipun memiliki latar belakang pendidikan yang tinggi. Ketiga, faktor nilai. Status perempuan dalam kehidupan sosial masih mengalami diskriminasi, terbukti masih kuatnya nilai tradisional dimana perempuan kurang memperoleh akses terhadap pendidikan, pekerjaan, pengambilan keputusan. Keempat, faktor budaya khususnya budaya patriarki, yang dalam perspektif patriarki, menjadi pemimpin dianggap sebagai hak bagi laki-laki, yang terkadang tidak disertai tanggung jawab dan cinta kepada istri. Kelima, faktor media massa sebagai agen utama budaya populer.

Perempuan dalam budaya populer adalah objek yang nilai utamanya adalah daya tarik seksual, pemanis, pelengkap, pemuas fantasi khususnya bagi pria. Keenam, faktor lingkungan yaitu adanya pandangan masyarakat yang ambigu. $^{1}$

Menurut banyak orang, adanya pembagian tugas yang cenderung memposisikan wanita hanya sebagai konco wingking (dalam bahasa jawa yang berarti teman belakang), tidak diperkenankan untuk bekerja selain urusan rumah tangga, sedangkan lelaki yang berperan sebagai pencari nafkah dan pemimpin keluarga menurut satu pendapat mengikuti pola keluarga tradisional. Sementara perempuan yang ikut bekerja karena tuntutan ekonomi atau aktualisasi diri disebut dengan tipe keluarga modern atau dual career.

Hasil penelitian Dyah Purbasari Kusumaning Putri dan Sri Lestari tentang keluarga tradisional menyebut adanya ajaran rukun yang menjadi pedoman dalam hubungan suami dan istri, terutama dalam keluarga Jawa. Hal tersebut terwujud dalam pembagian peran suami dan istri dalam tiga ranah, yakni pengambilan keputusan, pengelolaan keluarga dan pengasuhan anak. Ketiganya bersifat fleksibel, suami lebih banyak mengambil keputusan, sedangkan istri lebih berperan dalam pengelolaan dan pengasuhan anak. Tipologi keluarga seperti ini tidak diperkenankan adanya gejolak dalam rumah tangga. ${ }^{2}$ Pada konteks ini posisi perempuan inferior di mata sosial, karena tidak memiliki kekuatan dan kemandirian, terutama di bidang ekonomi. Hal yang lumrah terjadi pada semua keluarga dengan pola tradisional.

${ }^{1}$ Dyah Purbasari Kusumaning Putri dan Sri Lestari, Pembagian Peran Dalam Rumah Tangga Pada Pasangan Suami Istri Jawa, Jurnal Penelitian Humaniora, Vol. 16, No. 1, Februari 2015: 72-85, hal 72

2 Ibid, hal 73 
Lain halnya dengan keluarga tradisional yakni keluarga modern yang disebut juga dengan dual career (suami-istri bekerja). Hasil penelitian Shenoy terhadap 135 orang wanita di India memperoleh hasil yaitu marital stress (stress karena perkawinan) lebih menonjol atau lebih tinggi dialami oleh ibu rumah tangga, dibandingkan dengan wanita yang bekerja dan juga mengurus rumah tangga. Hasil berbeda dikemukakan oleh Khana terhadap 406 orang wanita. Penelitian tersebut menghasilkan temuan bahwa wanita yang bekerja lebih banyak mengalami kecemasan dan depresi daripada wanita yang tidak bekerja. $^{3}$

Pola keluarga dual career atau modern mengakibatkan sulitnya pembagian waktu antara tuntutan pekerjaan dan keluarga. Dikarenakan tuntutan pekerjaan itulah sering memunculkan konflik, seperti pekerjaan yang beresiko, peralatan kerja yang tidak memadai, tuntutan kerja dari atasan atau rekan dan lain sebagainya. Belum lagi konflik di dalam keluarga, seperti perdebatan mengenai keuangan, anak-anak, rekreasi, atau urusan keluarga lainnya. Sulitnya menyeimbangkan urusan pekerjaan dan keluarga dapat menimbulkan konflik pekerjaan keluarga (work-family conflict), dimana urusan pekerjaan mengganggu kehidupan keluarga atau urusan keluarga mengganggu kehidupan pekerjaan yang pada akhirnya dapat mempengaruhi kinerja baik suami ataupun istri yang bekerja.

Berangkat dari hasil penelitian terdahulu dan realita yang ada, penelitian ini bermaksud untuk mengetahui apa saja permasalahan yang muncul pada keluarga yang menerapkan pola tradisional dan dual career atau keluarga modern, khususnya yang berada di daerah Jember dan Banyuwangi yang notabene memiliki kultur pandhalungan (perpaduan antara jawa dan Madura), serta budaya osing. Budaya jawa selama ini dikenal memegang erat filosofi nenek moyang yakni nerimo ing pandum (menerima pemberian Yang Maha Kuasa) dan penyabar, sedangkan budaya Madura dikenal dengan watak keras, menang sendiri dan susah diatur (beberapa tempat). Dengan harapan hasil penelitian ini memberikan data pelengkap agar tercipta suatu pemahaman yang utuh tentang keluarga dan dinamikanya, serta muncul kesadaran akan tugas dan tanggung jawab masing- masing pasangan kepada lainnya, termasuk di dalamnya hak dan kewajiban mengurus, mengasuh dan mendidik anak-anak.

${ }^{3}$ Erni Pujiastuti \& Sofia Retnowati, Kepuasan Pernikahan dengan Depresi Pada Kelompok Wanita Menikah yang Bekerja dan yang Tidak Bekerja, Jurnal Humanitas: Indonesian Psychological Journal vol.1 no 2 Agustus 2004, hal 2 
Dari uraian tersebut di atas, penulis mencoba merumuskan masalah dalam artikel ini menjadi dua. Pertama, bagaimana dinamika keluarga tradisional dan permasalahannya? Kedua, bagaimana dinamika keluarga modern dan permasalahnnya?

\section{Kajian Teori}

Keluarga dalam kamus besar bahasa Indonesia menyebut sebagai bapak, ibu, dengan anak-anaknya, satuan kekerabatan yang sangat mendasar di masyarakat. ${ }^{4}$ Pendapat lain menyebut keluarga diartikan sebagai institusi terkecil dalam masyarakat yang berfungsi sebagai wahana untuk mewujudkan kehidupan yang tentram, aman, damai dan sejahtera dalam suasana cinta dan kasih sayang diantara anggota keluarga. Demikian juga keluarga terwujud dalam suatu ikatan hidup didasarkan karena adanya perkawinan atau juga disebabkan persusuan atau juga karena pengasuhan.

Terminology lain menyebut keluarga tercakup di dalamnya suami, istri, anak dan keturunan, kakek, nenek, saudara-saudara kandung dan anak-anak mereka, paman, bibi dan anaknya (sepupu). Sementara itu dalam terminolology psikologi, keluarga diartikan sebagai dua orang yang berjanji hidup bersama yang memiliki komitmen atas dasar cinta, menjalankan tugas dan fungsi yang saling terkait karena suatu ikatan batin atau hubungan perkawinan yang melahirkan ikatan sedarah, kesepahaman, watak, kepribadian yang satu lainnya saling mempengaruhi walaupun terdapat keragaman, menganut ketentuan norma, adat, nilai yang diyakini dalam membatasi keluarga dan yang bukan keluarga. ${ }^{5}$

Keluarga adalah kelompok sosial yang bersifat abadi, dikukuhkan dalam hubungan nikah yang memberikan pengaruh terhadap keturunan dan lingkungan sosial sebagai dimensi penting bagi anak. Tidak hanya itu saja keluarga menjadi tempat dimana anak memperoleh dasar dalam membentuk kemampuannya di bidang pendidikan, sosial, sikap dan kepribadian yang berguna di masyarakat kelak.

Masyarakat memandang bahwa keluarga menjadi satu lambang kehormatan bagi seseorang karena telah memiliki pasangan yang sah dan hidup wajar sebagaimana umumnya dilakukan oleh masyarakat. Keluarga dalam konteks masyarakat timur dipandang sebagai lambang kemandirian, karena awalnya seseorang masih memiliki ketergantungan pada orang tua maupun keluarga besarnya. Oleh karenanya perkawinan dianggap sebagai pintu ma-

${ }^{4}$ Mufidah, Psikologi Keluarga Islam Berwawasan Gender (Malang: UIN maliki press), 2014, hal 33.

${ }^{5}$ Ibid, hal 34 
suknya keluarga baru menjadi awal tanggung jawab baru dalam bingkai kehidupan yang baru.

Merujuk dari satu teori pada dasarnya sebuah keluarga dibagi menjadi dua bagian yakni Keluarga Tradisional dan Keluarga Modern. Keluarga tradisional dan keluarga modern dapat dilihat dari empat tipe komunikasi keluarga, yakni secara laissez- faire, protektif, pluralistik, dan konsensual. Keluarga Tradisional menurut Dagun memiliki ciri orang tua cenderung berinteraksi dan sering terlibat dalam permainan bersama anaknya, sementara Ibu cenderung membacakan cerita. Selama bermain dengan anak, ayah selalu melibatkan kontak fisik dan bermain diluar rumah, sedangkan ibu tidak demikian. Pada keluarga tradisional masih menerapkan aturan-aturan yang ketat bahkan sifatnya otoriter. Pada tipe komunikasi keluarga tradisional cenderung merujuk pada tipe komunikasi keluarga baik secara laissez-faire maupun juga secara protektif. Pada tipe komunikasi keluarga secara laissez-faire, sang anak tidak diarahkan untuk mengembangkan diri secara mandiri, artinya sang anak tidak memiliki kebebasan dalam menentukan sikap melainkan orang tua yang lebih dominan dalam mengarahkannya, sehingga komunikasi yang terjadi antara orang tua dan anak sangat rendah. Begitu juga dengan tipe komunikasi keluarga secara protektif atau sifatnya melindungi. ${ }^{6}$ Pada keluarga ini kepatuhan dan keselarasan sangat dipentingkan, artinya pada keluarga ini sangat menerapkan aturan-aturan yang ketat dalam mendidik anak.

Sementara itu pada keluarga modern sudah meninggalkan kebiasaan lama berganti dengan hal yang baru. Pada keluarga modern antara orang tua dan anak terdapat hubungan yang tidak otoriter atau berciri demokratis, seperti yang katakan oleh Ihromi dalam bukuinya yang berjudul "Sosiologi Keluarga". 7 Begitu juga kaitannya dengan tipe keluarga yang pluralistik yang menjalankan model komunikasi yang terbuka dalam membahas ide-ide dengan semua anggota keluarga, menghormati minat anggota lain termasuk sang anak dan saling mendukung. Tipe keluarga ini adalah salah satu tipe yang masuk pada kategori keluarga modern. Selain pluralistiik, tipe keluarga konsensual juga masuk dalam kategori keluarga ini (modern). Pada keluarga yang konsensual ditandai dengan adanya musyawarah mufakat. ${ }^{8}$ Artinya keluarga ini memberikan kesempatan untuk tiap anggota keluarga termasuk sang anak

${ }^{6}$ Regina Kansil, dkk, Fenomena Komunikasi Keluarga Tradisional Dan Keluarga Modern Dalam Membentuk Kepribadian Anak Di Kelurahan Bahu, e-journal "Acta Diurna" Volume VI. No. 3. Tahun 2017, hal 6

7 T.O. Ihromi, Sosiologi Keluarga, Bunga Rampai Sosiologi Keluarga (Jakarta: Yayasan Obor Indonesia), th 1999, hal 51

8 e-journal "Acta Diurna" Volume VI. No. 3. Tahun 2017, hal 7 
untuk mengemukakan pendapat atau ide, sehingga komunikasi dan suasana dalam keluarga lebih terbuka dan lebih demokratis, meskipun kedua orang tua kurang memiliki waktu yang banyak bersama anaknya karena kesibukan pekerjaan. Pada keluarga modern ayah tatkala terlibat sepenuhnya dalam mendidik anaknya. Cara berinteraksi sang ayah terhadap anaknya seperti mengajak anaknya bernyanyi, bercerita, dan juga menggambar dan tidak lagi melibatkan fisik dalam bermain dan mengajak bermain diluar rumah seperti pada keluarga tradisional.

Pendapat lain menyebut Keluarga tradisional ditandai dengan nilai-nilai tradisi yang masih dipegang erat dan dipertahankan oleh sebagian masyarakat. Jenis keluarga ini ditandai dengan pembagian kerja struktural dan fungsional yang sangat jelas, seperti halnya ayah sebagai kepala keluarga dan pencari nafkah utama, sedangkan istri atau ibu berperan sebagai pengatur rumah tangga dan pengasuh anak. Tipe keluarga tradisional masih tetap bertahan untuk mencegah diskontinuitas nilai. ${ }^{9}$ Diskontinuitas nilai dianggap penyebab utama keluarga berantakan hingga berujung pada melemahnya fungsi dan kontrol keluarga. Penyebab lain satu keluarga yang mempertahankan pola tradisional karena keluarga yang bersangkutan memang hampir tidak tersentuh oleh perubahan nilai yang sedang berlangsung, sehingga hampir tidak terjadi penyerapan nilai yang baru.

Istilah keluarga modern memunculkan istilah baru yaitu dual career yang didefinisikan sebagai "as those in managerial or professional jobs, with children, and spouse also in a managerial or professional job". Definisi lain menyebut "Dual-career is the situation where both spouses or partners have career responsibilities and aspiration". Apabila disimpulkan berarti dual career merupakan individu yang bersama pasangannya memiliki tanggung jawab karir dan pekerjaan baik di bidang manajerial maupun pekerjaan profesional lainnya. Dual-career memunculkan masalah baru apabila pasangan tersebut tidak dapat menyeimbangkan antara masalah pekerjaan dan masalah keluarga, seperti konflik yang terwujud dalam ketidak jelasan melakukan suatu pekerjaan (mana yang lebih prioritas).

Konflik pekerjaan terhadap keluarga (work family conflict) terjadi saat pengalaman dalam bekerja mempengaruhi kehidupan keluarga. Seperti tekanan dalam lingkungan kerja seperti jam kerja yang panjang, tidak teratur, tidak fleksibel, perjalanan yang jauh, beban kerja yang berlebihan dan bentuk- bentuk lainnya dari stress kerja, konflik interpersonal di lingkungan kerja, transisi

${ }^{9}$ Saparinah Sadli, Berbeda Tetapi Setara, Pemikiran Tentang Kajian Perempuan, Jakarta, kompas media nusantara, 2010 
karir, serta organisasi atau atasan yang kurang mendukung. Konflik keluarga terhadap pekerjaan (family-to work conflict) terjadi saat pengalaman dalam keluarga mempengaruhi kehidupan kerja. Contohnya seperti hadirnya anakanak yang masih kecil, merasa bahwa tanggung jawab utamanya adalah bagi anak- anak, bertanggung jawab merawat orang tua, konflik interpersonal dalam unit keluarga, serta kurangnya dukungan dari anggota-anggota keluarga. Guitian mengutip pendapat beberapa hasil penelitian sebelumnya yang menjelaskan bahwa konflik pekerjaan keluarga berkorelasi dengan ketidakhadiran pasangan, penurunan produktivitas, ketidakpuasan kerja, penurunan komitmen organisasi, kurangnya kepuasan hidup, kecemasan, kelelahan, distress psikologikal, depresi, penyakit fisik, penggunaan alkolhol, atau ketegangan dalam pernikahan. ${ }^{10}$

\section{Metode Penelitian}

\section{Desain dan responden penelitian}

Desain penelitian yang dipakai dalam penelitian ini adalah deskriptif kualitatif. Tempat atau lokasi penelitian dalam penelitian ini dipilih secara purposive (acak) yaitu Jember dan Banyuwangi Jawa Timur. Kedua kabupaten tersebut dipilih berdasarkan pertimbangan responden yang sesuai dengan tipologi keluarga. Jumlah responden yang terlibat dalam penelitian ini sebanyak 8 (delapan) keluarga. 4 (empat) keluarga mewakili keluarga tradisional (hanya suami yang bekerja) dan sisanya yaitu 4 keluarga mewakili keluarga modern (suami dan istri bekerja).

\section{Lokasi dan waktu penelitian}

Responden yang dijadikan sebagai subjek penelitian berasal dari Ledokombo, Mangli, Gebang, Ajung, Rambipuji (Jember), dan Cluring (Banyuwangi). Pelaksanaan penelitian dilakukan pada bulan Desember 2018 sampai dengan Januari 2019.

Teknik pengumpulan dan keabsahan data Data penelitian ini diperoleh melalui wawancara bebas dan terstruktur, dimana peneliti sebelumnya sudah mempersiapkan beberapa pertanyaan yang akan ditanyakan kepada responden. Sebagian peneliti juga menggunakan observasi non partisipan sebagai data pelengkap, sedangkan untuk mengukur kesahihan data peneliti menggunakan trianggulasi data dan trianggulasi sumber. ${ }^{11}$

10 Christine W.S., Megawati Oktorina, Indah Mula. Pengaruh Konflik Pekerjaan dan Konflik Keluarga Terhadap Kinerja dengan Konflik Pekerjaan Keluarga Sebagai Intervening Variabel (Studi pada Dual Career Couple di Jabodetabek) Hal 122

11 Sugiyono, Metode penelitian pendidikan, pendekatan kualitatif, Kuantitatif dan $R \mathcal{E} D$ 


\section{Pembahasan}

Bagaimana dinamika keluarga tradisional dan permasalahannya secara umum, individu dalam penelitian ini memiliki problematika yang hampir sama dengan keluarga lainnya, yakni suami yang sering menuntut istri ikut bekerja disaat suami tidak ada uang atau gaji yang diperoleh suami tidak mencukupi untuk memenuhi kebutuhan hidup sehari-harinya. Tuntutan tersebut terkadang juga disertai dengan ucapan yang menyakitkan hati istri. Seolaholah suami menutup mata atas apa yang sudah dikerjakan istri di rumah. Dalam hal ini istri dituntut berperan ganda dalam rumah tangga, yakni dituntut untuk ikut bekerja membantu perekonomian suami, namun juga dibebani tugas rumah tangga lainnya, seperti memasak, mencuci, membersihkan rumah dan merawat anak- anak.

Muncul suatu hegemoni yang kuat suami atas istrinya, karena suami yang mencari nafkah, sedangkan istrinya tidak. Istri tidak punya kuasa atas apa yang diucapkan dan dilakukan suaminya. Perilaku tersebut tidak lepas dari hierarki sosial dan pranata sosial dimana lelaki lebih punya kuasa daripada laki-laki.

Sedikit berbeda dengan hasil tersebut data yang diperoleh dari keluarga lainnya. Dimana hasil penelitian menunjukkan sikap istri yang terkadang menuntut materi lebih dari yang telah diberikan suami. Ada semacam ketidakpuasan atas apa yang selama ini telah diterimanya, sehingga hal ini berdampak pada percekcokan antar keduanya. Masing-masing pasangan menyalahkan satu dengan lainnya, suami menyalahkan istri yang tidak mampu mengatur keuangan keluarga, sementara istri menyalahkan suami yang hanya memberikan nafkah materi yang sedikit dengan berbagai macam kebutuhan yang ada.

Mengutip pendapatnya Mufidah adanya ucapan yang kasar kepada istri dapat dikategorikan sebagai bentuk KDRT (kekerasan dalam rumah tangga). ${ }^{12}$ KDRT tidak hanya berupa kekerasan fisik, namun bisa juga berbentuk kekerasan seksual, kekerasan psikis dan penelantaran ekonomi, seperti tidak adanya pemberian nafkan lahir atau nominal yang diberikan suami kepada istri jauh dari kata cukup untuk kebutuhan sehari-hari.

Kekerasan dalam rumah tangga lazim terjadi di masyarakat disebabkan oleh beberapa hal, seperti interpretasi agama yang tidak sesuai dengan nilai universal agama. Kedua, budaya patriachi yang menempatkan posisi pihak yang memiliki kekuasaan merasa lebih unggul. Ketiga kekerasan yang berlangsung mendapatkan legitimasi masyarakat dan menjadi bagian dari bu-

(Bandung: Alvabeta), 2012, hal 46

12 Mufidah, Psikologi Keluarga Islam Berwawasan Gender,...hal, 244. 
daya, keluarga, negara dan praktik di masyarakat, sehingga menjadi bagian kehidupan yang sulit dihapuskan. Keempat, stereotype yang merugikan, seperti laki-laki kasar, macho dan perkasa, sedangkan perempuan lemah dan mudah menyerah jika mendapatkan perlakuan kasar.

Masalah kedua yang muncul pada keluarga tradisional adalah sikap suami yang acuh tak acuh (tidak peduli) dengan pola asuh dan pendidikan yang diterapkan istri kepada anak-anaknya. Responden (suami) dalam penelitian ini hanya melakukan kewajibannya untuk memenuhi dan menafkahi kebutuhan ekonomi/materi saja, sedangkan yang lainnya tidak. Seorang suami kurang memposisikan dirinya sebagai orang yang juga ikut bertanggung jawab atas keluarga yang dibangunnya. Ada sebuah kepercayaan penuh suami kepada istri tentang pengasuhan dan pendidikan anak. Akan tetapi apabila sesuatu yang tidak diinginkan menimpa pada anak seperti kecelakaan, kenakalan atau prestasi akademik yang tidak bagus, maka suami akan melimpahkan kesalahan sepenuhnya kepada istri.

Perselingkuhan menjadi permasalahan berikutnya dalam keluarga tradisional. Hal ini dipicu oleh kebosanan suami terhadap istri yang disebabkan oleh banyak hal, salahsatunya kepuasan perkawinan. Suami membutuhkan hiburan dalam kesibukannya selama bekerja, sedangkan istri merasakan suatu kebebasan saat berada di rumah sendiri saat suami bekerja. Adriana Soekandar menyebut dalam penelitiannya perselingkuhan yang terjadi tidak hanya disebabkan oleh ketidakpuasan dalam pernikahan, namun beberapa masalah yang terakumulasi selama beberapa waktu, seperti kecemasan menghadapi masa transisi setelah memiliki anak pertama, anak masuk sekolah atau setelah memasuki masa pensiun. Faktor lainnya dipengaruhi oleh tidak tercapainya harapan-harapan dalam perkawinan, kesepian, kebutuhan akan kasih sayang dari pasangan perkawinan. ${ }^{13}$

Responden dalam penelitian ini juga menyebut rasa capek sepulang kerja, jarak tempuh pekerjaan yang jauh, tekanan pekerjaan seringkali menjadikan komunikasi antar suami dan istri menjadi kurang. Demikian juga komunikasi dengan anak menjadi berkurang, hingga akhirnya anggota keluarga dalam rumah tangga itu merasakan haus akan kasih sayang dari ayah dan juga suami hingga terjadilah percekcokan. Masalah lain yang menjadi variabel pendukung adanya percekcokan adalah suami yang membawa masalah kantor dan pekerjaan ke rumah. Keluarga yang di rumah seringkali menjadi tempat meluapkan emosi setelah dimarahi oleh atasan. Padahal keluarga yang di rumah tidak

${ }^{13}$ Adriana Soekandar Ginanjar, Jurnal Makara, Sosial Humaniora vol 13 no 01 Juli 2009, hal 68 
mengetahui yang sedang terjadi di tempat kerja, itulah yang disebut dengan work conflict.

Sebagai pembanding, hasil penelitian yang dilakukan oleh Long terhadap 571 wanita di Chicago Amerika Serikat yang melakukan pernikahan dengan model konvensional (hanya suami yang bekerja) menyebut individu dalam keluarga itu lebih konservatif (tertutup), individu memiliki ketergantungan yang tinggi secara finansial dan emosional kepada pasangannya, sehingga lebih banyak mengalami gangguan mental, neorosis dan gangguan psikologis. Sementara itu istri yang bekerja ternyata menunjukkan kepuasan pernikahan yang lebih tinggi, meskipun stress yang dialami juga ikut tinggi. Long menyebut tingkat pendidikan dan hubungan sosial mempunyai pengaruh yang signifikan terhadap tingkat kepuasan individu. ${ }^{14}$ Demikian juga penelitian yang dilakukan oleh Shenoy pada 135 wanita di India bahwasanya ibu rumah tangga memiliki angka stress lebih tinggi daripada istri yang bekerja.

\section{Bagaimana dinamika keluarga modern dan permasalahnnya}

Secara global, Istri bekerja mampu memberikan kontribusi terhadap perekonomian keluarga, namun disisi lain istri mempunyai peran ganda. Data yang terkumpul dari responden menunjukkan data bahwa suami dan istri yang bekerja komunikasi antar anggota keluarga menjadi minim, disebabkan oleh aktivitas masing- masing. Diantara responden bersama-sama berangkat pagi hari dan kembali menjelangmalam harinya, atau sebaliknya suami berangkat pagi hari dan istri berangkat pada siang atau sore harinya. Karena faktor komunikasi itulah memunculkan sikap egoisme/menang sendiri pada masing- masing pasangan, hal tersebut juga diperkuat dengan kemandirian secara ekonomi dari masing-masing pasangan terutama istri.

Data lain yang diperoleh dari responden diantaranya yaitu:

a) Adanya beban ganda pada istri yang yang bekerja, yaitu mengurus rumah tangga dan anak-anak, istri juga bertanggung jawab pada pekerjaannya di luar rumah. Tidak jarang salah satu dari beban yang ditanggung oleh istri yang bekerja tidak bisa dilaksanakan secara maksimal, karena harus ada yang diprioritaskan, sehingga menyebabkan istri gagal pada tugas yang lainnya.

b) Waktu untuk berkumpul dengan keluarga menjadi terbatas. Waktu yang dimiliki oleh istri yang bekerja banyak dihabiskan untuk bekerja, sehingga waktu berkumpul dengan anggota keluarganya terutama suami dan

14 Erni Pujiastuti \& Sofia Retnowati, Jurnal Humanitas: Indonesian Psycologycal Journal vol 1 no 2 Agustus 2004, hal 1. 
anaknya menjadi terbatas, mengingat suami juga ikut bekerja. Suami dan Istri hanya dapat bertemu pada saat pagi hari menjelang berangkat kerja dan anak-anak sebelum berangkat ke sekolah atau disaat malam harinya. Muncul rasa bersalah pada istri terhadap anak karena tidak bisa mengurus dan mendampingi secara maksimal perkembangan dan pertumbuhan anak.

c) Berkurangnya kelembutan, keramahan dan kegembiraan dari suami dan anak-anak. Bahkan tidak jarang muncul keributan dan keluhan-keluhan seputar pekerjaan dan persaingan dari masing-masing pasangan. Tidak jarang juga suami kehilangan kepemimpinan karena istri juga ikut bekerja, terlebih jika gaji dan jabatan istri lebih besar daripada suami.

Hasil tersebut memperkuat hasil penelitian yang dilakukan oleh Fitri Meliani dkk. Penelitian tersebut menyebut tuntutan pekerjaan yang tinggi menjadi embrio kemunculan konflik dalam rumah tangga sebesar 58,3\%, disusul kemudian dengan sulitnya memenuhi tanggung jawab dalam keluarga 53,9\% dan kegiatan di rumah tidak dapat diselesaikan dengan baik. ${ }^{15}$

Keluarga lain dalam penelitian ini menyebut adanya kesibukan pekerjaan dan rumah tangga memiliki konsekuensi merasa jauh dengan Tuhan, kecenderungan untuk berselingkuh semakin tinggi, jauh dengan tetangga sekitar dan banyaknya pekerjaan rumah tangga yang terbengkalai. Responden lainnya menyebut berkurangnya kepercayaan dan harga diri suami di mata istri apabila secara materi yang diperoleh istri lebih banyak daripada suami, serta berkurangnya interaksi dan komunikasi dengan anak. Istri lebih mudah tersinggung dengan ucapan suami sepulang kerja, sementara suami kurang peka dengan kondisi fisik dan psikis istrinya yang juga ikut bekerja. Suami apatis dengan pengasuhan dan pendidikan anak, cenderung pemarah, serta abai dengan kebutuhan biologis istri.

Disebabkan oleh status perempuan yang bekerja, ditemukan banyak hal yang tidak bisa dilakukan secara normal oleh mereka yang bekerja, banyak pekerjaan yang terbengkalai. Hal inilah yang akhirnya memunculkan konflik ganda menurut Greenhaus \& Beutell. Keduanya menyebut konflik ganda adalah suatu bentuk konflik peran dimana tekanan-tekanan dari pekerjaan dan keluarga saling tidak cocok. Sementara itu Paden \& Buchler mendefinisikan konflik peran ganda merupakan konflik peran yang muncul antara harapan dua peran berbeda yang dimiliki oleh seseorang. Serupa dengan Paden, dkk apa yang disampaikan oleh Netemeyer dkk yang mendefinisikan konflik pe-

${ }^{15}$ Fitri Meliani, dkk, jurnal ilmu keluarga dan konseling, faktor demografi, konflik kerja keluarga, dan kepuasan perkawinan istri bekerja, September 2014, p: 133-142, ISSN : 1907-6037, hal 136 
ran ganda sebagai konflik yang muncul akibat tanggung jawab yang berhubungan dengan pekerjaan yang menimbulkan ketegangan dalam keluarga. ${ }^{16}$

Aspek-aspek konflik peran ganda perempuan bekerja menurut Kopelman yaitu; (1) pengasuhan anak, (2) bantuan pekerjaan rumah tangga, (3) komunikasi dan interaksi dengan anak dan suami, (4) waktu untuk keluarga, (5) menentukan prioritas, (6) tekanan karir dan tekanan keluarga, serta (7) pandangan suami terhadap peran ganda wanita.

Hampir serupa dengan pernyataan tersebut hasil penelitian yang dikemukakan oleh Jones \& Jones. Penelitian tersebut menyebut jika sikap suami merupakan faktor yang penting dalam menentukan keberhasilan dual-career marriage (suami- istri bekerja). Ada suami yang merasa terancam, tersaingi dan cemburu dengan status pekerjaan istrinya, ada yang tidak menganggap pekerjaan istri menjadi masalah, selama istrinya tetap dapat memenuhi dan melayani kebutuhan suami. Namun ada suami yang justru mendukung karir istrinya dan ikut bekerja sama dalam urusan rumah tangga sehari-hari sehingga istri dapat merasakan kepuasan dan kebahagiaan dalam keluarga dan karirnya.

Sementara itu penelitian tentang kepuasan dan kebahagiaan hidup perempuan yang bekerja oleh Ferree menunjukkan bahwa perempuan yang bekerja menunjukkan tingkat kepuasan hidup sedikit lebih tinggi dibandingkan dengan perempuan yang tidak bekerja. Ukuran kebahagiaan hidup perempuan yang sudah menikah diteliti oleh Freudiger ditinjau dari tiga kategori, yaitu: perempuan bekerja, pernah bekerja dan yang belum pernah bekerja, menunjukkan bahwa bagi perempuan bekerja, kebahagiaan perkawinan tetap menjadi hal yang utama dibandingkan dengan kepuasan bekerja.

Pernyataan tersebut diperkuat oleh hasil penelitian Scanzoni yang mengungkapkan bahwa perkawinan dual-career dikatakan berhasil jika di antara kedua belah pihak (suami dan istri) saling memperlakukan pasangannya sebagai partner yang setara. Dimana mereka tidak hanya akan berbagi dalam hal penghasilan, namun juga berbagi dalam urusan rumah tangga dan pengasuhan anak-anak.

Di lain pihak hasil penelitian Pengembangan Kesejahteraan Sosial Depsos melaporkan bahwa meskipun perempuan mempunyai jabatan dengan berbagai kesibukan masih dapat melaksanakan peran gandanya, yaitu tidak meninggalkan perannya sebagai ibu rumah tangga dan pekerjaan, mereka tetap berusaha menjadi ibu dan istri yang baik, berinteraksi dengan keluarga juga masih terjalin dengan baik.

16 Apollo dan Adi Cahyadi, Konflik Peran Ganda Perempuan Menikah Yang Bekerja Ditinjau Dari Dukungan Sosial Keluarga dan Penyesuaian Diri, Jurnal Widya Warta, No. 02 Tahun XXXV I/ Juli 2012, hal 260. 
Masalah mendasar pada keluarga dengan suami dan istri bekerja adalah keterbatasan waktu untuk melakukan kewajiban, baik terhadap pekerjaan ataupun keluarga. Apabila tidak terjadi keseimbangan peran istri pada tempat kerja dan rumah tangga maka akan berdampak negative pada kebutuhan anggota keluarga, kebahagiaan dan perkembangan suatu keluarga. Tentunya hal itu tidak diinginkan oleh siapapun, mengingat statistik perceraian semakin meningkat setiap tahunnya dan percereraian tersebut diinisiasi oleh istri. ${ }^{17}$

Penelitian lainnya menyebut kepuasan perkawinan dipengaruhi oleh kerja dan keluarga. Istri yang dapat menangani konflik kerja dan keluarga dengan baik cenderung lebih puas dengan perkawinannya. Kebanyakan pekerja menyebut bahwa keluarga lebih penting dari pekerjaan, dan penelitian membuktikan bahwa konflik kerja mengganggu keluarga lebih sering terjadi dibandingkan dengan konflik keluarga mengganggu kerja. Penelitian lain menyebut Wanita dan istri yang bekerja pada umumnya merasa lebih bahagia dan puas terhadap pernikahannya, karena ia dapat melepaskan diri dari ketergantungan yang berlebihan pada suami, mampu berpenghasilan sendiri (meski lebih kecil jumlahnya), serta memiliki lingkup pergaulan yang lebih luas dan bervariasi. Selain itu merasakan hidup yang lebih berarti dan memiliki harga diri yang lebih tinggi. ${ }^{18}$

\section{Kesimpulan}

Penelitian tentang tipologi keluarga tradisional dan modern atau yang disebut juga dengan dual career terutama yang berkaitan erat dengan permasaalahan yang muncul tentunya bersifat relatif, disebabkan oleh banyak hal, salah satunya faktor budaya dan karakteristik individu. Namun secara global keluarga tradisional dan dual career dalam penelitian ini masalah yang muncul diantaranya yaitu tuntutan dari suami agar supaya istri juga ikut bekerja, terutama saat kondisi ekonomi kurang bagus. Adanya tuntutan itu disertai dengan kekerasan dalam rumah tangga (KDRT) yang terwujud dalam bentuk non verbal. Masalah kedua yang muncul dari keluarga tradisional adalah suami acuh tak acuh perihal pengasuhan anak, dan masalah ketiga adalah perselingkuhan.

Sementara itu masalah yang muncul pada keluarga dual career diantaranya adalah terkikisnya wibawa suami di depan istri. Disebabkan oleh berku-

${ }^{17}$ Fitri Meliani, dkk, jurnal ilmu keluarga dan konseling, faktor demografi, konflik kerja keluarga, dan kepuasan perkawinan istri bekerja, September 2014, p: 133-142, ISSN : 1907-6037

18 Erni Pujiastuti \& Sofia Retnowati, kepuasan pernikahan dengan depresi pada kelompok wanita menikah yang bekerja dan yang tidak bekerja, hal 3 
rangnya ketergantungan istri terhadap suami dalam hal materi. Masalah berikutnya adalah konflik yang dialami oleh istri, karena bingung menentukan prioritas utama yang harus diambil, apakah urusan keluarga atau pekerjaan kantor, serta berkurangnya kehangatan dalam keluarga dan minimnya komunikasi antar semua anggota keluarga.

\section{Saran}

Berdasarkan hasil penelitian dan pembahasan, peneliti berharap:

a. Bagi keluarga tradisional dan dual career Diharapkan bagi keluarga atau individu yang menerapkan pola perkawinan tradisional ataupun modern (dual career) mampu membangun satu komunikasi yang intens antar pasangan dalam setiap aktivitasnya, saling menghargai, menghormati dan memahami tanggung jawab masing-masing individu kepada lainnya. Dengan harapan masalah dalam keluarga yang bersifat fatal dapat diminimalisir dan dipecahkan secara bersama-sama guna mewujudkan keluarga yang sejahtera dan tercapai perkembangan individu yang bermental sehat.

b. Bagi peneliti selanjutnya

Keterbatasan penelitian ini adalah kurangnya anteseden dalam melihat satu perilaku dalam suatu keluarga, seperti faktor budaya, usia pernikahan dan usia perkembangan individu, faktor pendidikan dan jenis kelamin. Diharapkan pada peneliti berikutnya dapat menyajikan data terkait masalah keluarga secara lebih detail.

\section{Daftar Pustaka}

Mufidah, Psikologi Keluarga Islam Berwawasan Gender (Malang: UIN maliki press), 2014

Sugiyono, Metode penelitian pendidikan, pendekatan kualitatif, Kuantitatif dan $R$ \& D (Bandung: Alvabeta), 2012

T.O. Ihromi, Sosiologi Keluarga, Bunga Rampai Sosiologi Keluarga (Jakarta: Yayasan Obor Indonesia), th 1999

Adriana Soekandar Ginanjar, Jurnal Makara, Sosial Humaniora vol 13 no 01 Juli 2009

Apollo dan Adi Cahyadi, Konflik Peran Ganda Perempuan Menikah Yang Bekerja Ditinjau Dari Dukungan Sosial Keluarga dan Penyesuaian Diri, Jurnal Widya Warta, No. 02 Tahun XXXV I/ Juli 2012 Christine W.S., Megawati Oktorina, Indah Mula. Pengaruh Konflik Pekerjaan dan Konflik Keluarga Terhadap Kinerja dengan Konflik Pekerjaan Keluarga Sebagai Intervening Variabel (Studi pada Dual Career Couple di Jabodetabek)

Dyah Purbasari Kusumaning Putri dan Sri Lestari, Pembagian Peran Dalam Ru- 
mah Tangga Pada Pasangan Suami Istri Jawa, Jurnal Penelitian Humaniora, Vol. 16, No. 1, Februari 2015 e-journal "Acta Diurna" Volume VI. No. 3. Tahun 2017

Erni Pujiastuti \& Sofia Retnowati, Kepuasan Pernikahan dengan Depresi Pada Kelompok Wanita Menikah yang Bekerja dan yang Tidak Bekerja, Jurnal Humanitas: Indonesian Psychological Journal vol.1 no 2 Agustus 2004

Fitri Meliani, dkk, jurnal ilmu keluarga dan konseling, faktor demografi, konflik kerja keluarga, dan kepuasan perkawinan istri bekerja, September 2014, p: 133-142, ISSN : 1907-6037,

Regina Kansil, dkk, Fenomena Komunikasi Keluarga Tradisional Dan Keluarga Modern Dalam Membentuk Kepribadian Anak Di Kelurahan Bahu, e-journal "Acta Diurna" Volume VI. No. 3. Tahun 2017

Saparinah Sadli, Berbeda Tetapi Setara, Pemikiran Tentang Kajian Perempuan, Jakarta, kompas media nusantara, 2010 
